\title{
Article \\ Behaviour of Metal(loid)s at the Sediment-Water Interface in an Aquaculture Lagoon Environment (Grado Lagoon, Northern Adriatic Sea, Italy)
}

\author{
Elisa Petranich ${ }^{1}$, Matteo Crosera ${ }^{2}$, Elena Pavoni ${ }^{1,2}$, Jadran Faganeli ${ }^{3, *}$ and Stefano Covelli ${ }^{1}[$ \\ 1 Dipartimento di Matematica e Geoscienze, Università degli Studi di Trieste, Via Weiss 2, 34128 Trieste, Italy; \\ epetranich@units.it (E.P.); epavoni@units.it (E.P.); covelli@units.it (S.C.) \\ 2 Dipartimento di Scienze Chimiche e Farmaceutiche, Università degli Studi di Trieste, Via Licio Giorgieri 1, \\ 34127 Trieste, Italy; mcrosera@units.it \\ 3 Marine Biology Station, National Institute of Biology, Fornace 41, 6330 Piran, Slovenia \\ * Correspondence: jadran.faganeli@nib.si
}

check for

updates

Citation: Petranich, E.; Crosera, M.; Pavoni, E.; Faganeli, J.; Covelli, S. Behaviour of Metal(loid)s at the Sediment-Water Interface in an Aquaculture Lagoon Environment (Grado Lagoon, Northern Adriatic Sea, Italy). Appl. Sci. 2021, 11, 2350. https://doi.org/10.3390/app11052350

Academic Editor: Mónica Calero de Hoces

Received: 30 January 2021

Accepted: 3 March 2021

Published: 6 March 2021

Publisher's Note: MDPI stays neutral with regard to jurisdictional claims in published maps and institutional affiliations.

Copyright: (c) 2021 by the authors. Licensee MDPI, Basel, Switzerland. This article is an open access article distributed under the terms and conditions of the Creative Commons Attribution (CC BY) license (https:// creativecommons.org/licenses/by/ $4.0 /)$.

\begin{abstract}
The cycling of metal(loid)s at the sediment-water interface (SWI) was evaluated at two selected sites (VN1 and VN3) in an active fish farm in the Grado Lagoon (Northern Adriatic, Italy). In situ experiments using a transparent benthic chamber and the collection of short sediment cores were performed, to investigate the behavior of metal(loid)s in the solid (sediments) and dissolved (porewaters) phases. Total and labile concentration of metal(loid)s were also determined in sediments, to quantify their potential mobility. Comparable total concentrations were found at both sites, excluding As, Mn, Pb and V, which were higher at VN3. Metal(loid) porewater profiles showed a diagenetic sequence and a close dependence with redox (suboxic/anoxic) conditions in the surface sediments. Positive diffusive fluxes along with benthic fluxes, particularly at the more oxic site, VN1, were found for almost all metal(loid)s, indicating their tendency to migrate towards the overlying water column. Despite sediments at two sites exhibiting high total metal(loid) concentrations and moderate effluxes at the SWI, the results suggest that they are hardly remobilized from the sediments. Recycling of metal(loid)s from the SWI would not constitute a threat for the aquatic trophic chain in the fish farm.
\end{abstract}

Keywords: metal(loid)s; contamination; porewaters; benthic fluxes; fish farm; Northern Adriatic

\section{Introduction}

Sediments are a critical compartment of aquatic ecosystems where natural and anthropogenic chemical substances accumulate. Metal(loid)s represent a serious threat to the marine environment due to their potential toxicity, relative abundance, persistence and bioaccumulation throughout the whole trophic chain. The study of their behavior and cycling at the sediment-water interface (SWI) is of great importance and allows for the planning of possible mitigation actions. The SWI represents the upper limit between the sediment and the overlying water column where the biogeochemical cycles of elements, such as metal(loid)s, interact with each other, contributing to their release from sediment, temporarily accumulated and immobilized in the solid phase, to the overlying water column [1]. Dissolved metal(loid)s can return to the bottom sediments through precipitation and/or adsorption on the surface of the suspended particulate matter (SPM) and its subsequent settling. Because sediments can act as an ultimate reservoir (sink) to store contaminants, they are suitable indicators for monitoring water quality [2] and/or to act as a secondary source of contamination, following natural and anthropogenic events [3]. Moreover, the biogeochemical processes that occurred in sediments can also mobilize [4] and transform metal(loid)s into more toxic chemical forms as a result of their physicochemical alterations [5], thus becoming potentially available for biota [6,7]. The SWI 
plays an important role in the assessment of metal contamination in aquatic environments, especially in the transitional systems such as lagoons.

The Marano and Grado Lagoon (Northern Adriatic Sea, Italy) is affected by a high degree of mercury $(\mathrm{Hg})$ contamination in sediments originating from the Idrija mine (NW Slovenia) and the decommissioned chlor-alkali plant of Torviscosa (Italy) [8]. In addition, previous studies reported an evident accumulation of other metal(loid)s in the lagoon subtidal sediments caused by industrial, urban and tourist activities [9-11].

In this research, we evaluated the mobility of metal(loid)s (As, $\mathrm{Cd}, \mathrm{Cr}, \mathrm{Cu}, \mathrm{Fe}, \mathrm{Hg}$, $\mathrm{Mn}$, $\mathrm{Ni}, \mathrm{Pb}$ and $\mathrm{Zn}$ ) at the SWI in a lagoon environment modified for aquaculture purposes (fish farm) previously investigated for $\mathrm{Hg}$ contamination in sediments and its bioavailability for farmed fish species [12], as well as for nutrient cycling through the SWI [13]. The potential mobility of metal(loid)s from the sediment to porewaters and to the overlying water column was assessed by estimating diffusive and benthic fluxes as a consequence of diagenetic redox reactions involved in the remineralisation of organic matter. The results can be useful in understanding the mobility of the metal(loid)s in this compartment thus providing useful information to improve the environmental quality of this modified aquatic system.

\section{Materials and Methods}

\subsection{Study Area}

The Val Noghera fish farm is one of the few fish farms still active in the Marano and Grado Lagoon (Northern Adriatic Sea, Italy) and is considered one of the greatest and most productive (Figure 1). The fish farm was constructed by building a perimeter of man-made embankments in the lagoon environment. Sluice gates are the only method of water exchange between the fish farm and the lagoon environment. The fish farm covers a surface area of 220 ha, with a dense network of primary and secondary channels, salt marshes and fish ponds.

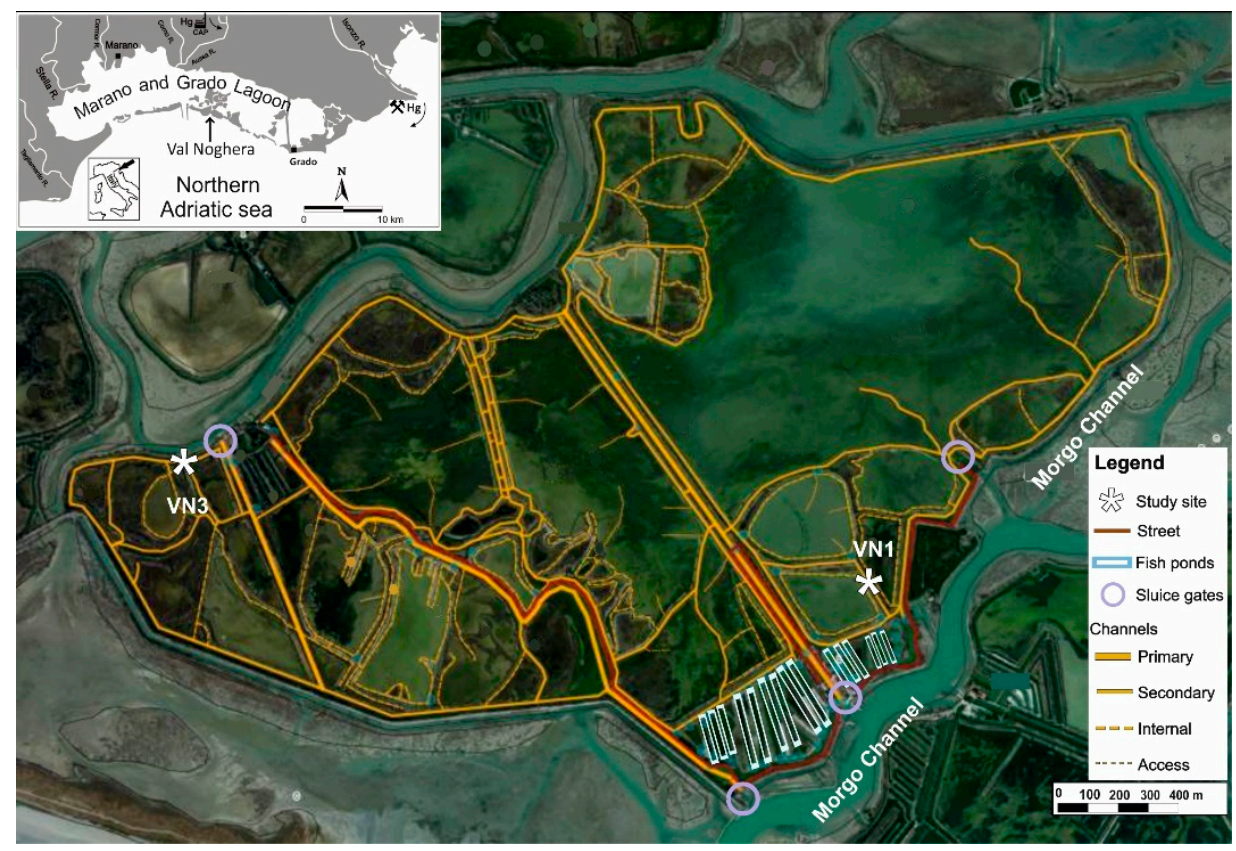

Figure 1. Study area: Val Noghera fish farm with the two sampling sites, VN1 and VN3, located in two of the channels belonging to different sectors of the Marano and Grado coastal lagoon.

Previous investigations carried out in the Val Noghera fish farm, regarding $\mathrm{Hg}$ biogeochemical cycling at the SWI [12] and the recycling of organic matter and nutrients [13], highlighted that these biogeochemical processes are enhanced compared to those in the open lagoon [14,15]. We investigated the presence and mobility of other metal(loid)s in the sediments to evaluate if, following the biogeochemical processes at the SWI, they can be 
transferred, in dissolved form, to the water column, becoming a potential risk to be taken up by the farmed fish. The selected sampling sites, VN1 and VN3 (Figure 1), are located in two primary channels of the fish farm belonging to two sectors with different hydrodynamics. Site VN1 $\left(45^{\circ} 42^{\prime} 36.78^{\prime \prime} \mathrm{N} ; 13^{\circ} 18^{\prime} 29.83^{\prime \prime} \mathrm{E}\right)$ is located in the eastern sector (built in the $\left.60^{\prime} \mathrm{s}\right)$, where the water recirculation is more intense than that of VN3 $\left(45^{\circ} 42^{\prime} 49.80^{\prime \prime} \mathrm{N}\right.$; $13^{\circ} 17^{\prime} 15.27^{\prime \prime} \mathrm{E}$ ), which is located in the western sector (constructed at the beginning of the 19 th century) $[12,13]$.

The experiments were performed in July-August 2015, during the season of intense microbiological activity $[14,16,17]$. The elevated temperature appears to enhance the availability of some metals also by accelerating the degradation of organic matter in the surface sediments [13], which can release some elements bound to the organic fraction (70-80\%) and stimulating the microbial transformation of some metals into a more toxic form [12].

\subsection{Sampling}

An in situ transparent benthic chamber equipped with a stirring mechanism was carefully deployed by a scuba diver at the bottom, thus isolating an area of about $0.25 \mathrm{~m}^{2}$ of sediments together with an approximately $30 \mathrm{~cm}$ of the water column. Water samples were collected with $50 \mathrm{~mL}$ polypropylene syringes, at approximately $2 \mathrm{~h}$ intervals (from $\mathrm{T}_{0}=0$ to $\mathrm{T}_{4}=8 \mathrm{~h}$ ). The collected water was filtered through $0.45 \mu \mathrm{m}$ pore size (Millipore Millex HA) membrane filters, transferred into the specific vials and stored until analytical determinations [14]. The water sample aliquots for dissolved metal(loid)s were immediately acidified with $\mathrm{HNO}_{3}(1 \%, v / v, \mathrm{VWR} \geq 69 \%)$ whereas the samples for $\mathrm{Hg}$ determination were immediately oxidised with bromine chloride $\mathrm{BrCl} \mathrm{Hg}$-free from Brooks Rand Instruments, $0.5 \%$ $v / v$, until the colour of the sample turned yellow). Water temperature, conductivity, $\mathrm{pH}$, redox potential (Eh) and dissolved oxygen were recorded, using a multiparameter probe (YSI Professional Plus Multiparameter Meter) directly inserted into the benthic chamber.

In parallel, undisturbed short sediment cores $(30 \mathrm{~cm} \varnothing, 16 \mathrm{~cm}$ in length) with the overlying (supernatant) water were collected. These cores were extruded in a $\mathrm{N}_{2}$-filled chamber in the laboratory, to preserve the original redox conditions and, after supernatant water collection, sectioned into discrete levels $(0-1,1-2,2-3.5,3.5-5$, and $5-7 \mathrm{~cm})$. The porewaters were extracted by centrifugation $(5000 \mathrm{rpm} ; \mathrm{t}=14 \mathrm{~min})$ at in situ temperature, filtered through Millipore Millex HA membrane filters ( $0.45 \mu \mathrm{m}$ pore size) and stored at $4{ }^{\circ} \mathrm{C}$ until analysis. The sediment samples were divided into three aliquots for subsequent analyses and freeze-dried.

\subsection{Solid Phase Analysis}

For grain-size analysis, approximately $15-20 \mathrm{~g}$ of fresh sediment was treated with $\mathrm{H}_{2} \mathrm{O}_{2}(3 \%)$ for a minimum of $24 \mathrm{~h}$, to eliminate most of the organic matter. Subsequently, the sediment was wet-sieved through a $2 \mathrm{~mm}$ sieve, to remove coarse shell fragments. The resulting $<2 \mathrm{~mm}$ fraction was analyzed, using a laser granulometer (Malvern Mastersizer, 2000). Total and organic carbon $\left(\mathrm{C}_{\text {tot }}\right.$ and $\left.\mathrm{C}_{\text {org }}\right)$ and nitrogen $\left(\mathrm{N}_{\text {tot }}\right)$ content were determined by using an ECS 4010 Elemental Combustion System, Costech. $\mathrm{C}_{\text {tot }}$ and $\mathrm{N}_{\text {tot }}$ were determined at a combustion temperature of $1020{ }^{\circ} \mathrm{C}$ and $\mathrm{C}_{\text {org }}$ at $920^{\circ} \mathrm{C}$ [18], after progressive acidification with $0.1-1.0 \mathrm{M} \mathrm{HCl}$ (prepared from $37 \% \mathrm{HCl}$, Honeywell Fluka), to remove carbonates.

The EPA Method 3052 [19] was applied, to determine total metal(loid) (As, Cd, Co, $\mathrm{Cr}, \mathrm{Cu}, \mathrm{Fe}, \mathrm{Mn}, \mathrm{Ni}, \mathrm{Pb}, \mathrm{V}$ and $\mathrm{Zn}$ ) contents. Three aliquots of PACS-3, a certified reference material (Marine Sediment, NRCC, Whitehorse, YT, Canada), were mineralized with the sediment samples, to verify the accuracy of the procedure. The solutions obtained were analyzed by Inductively Coupled Plasma Optical Emission Spectrometry (ICP-OES), using an Optima 8000 Spectrometer (Perkin Elmer, Waltham, MA, USA), equipped with an S10 autosampler. The measurements were conducted by using calibration curves obtained by dilution (range: $0.1-10 \mathrm{mg} / \mathrm{L}$ ) of the standard solutions for ICP analyses (Sigma-Aldrich, St. Louis, MO, USA). Total Hg (THg) was determined by using a Direct Mercury Analyzer 
(DMA-80, Milestone, Sorisole, Italy), according to the EPA Method 7473 [20]. The limit of detection (LOD) was approximately $0.005 \mathrm{ng}$. The accuracy of the methods for analytical determination of trace elements was checked, using the certified reference material (PACS3), and acceptable recoveries were obtained, ranging between 86 and $98 \%$.

In addition, a weak extraction with $0.5 \mathrm{M} \mathrm{HCl}$ was performed to assess the amount of the elements in association with Fe and Mn oxides and hydroxides [21]. The obtained extracts were analyzed by using a Perkin Elmer (Waltham, MA, USA) NexION 350X Inductively Coupled Plasma-Mass Spectrometry (ICP-MS), working in kinetic energy discrimination (KED) mode, using ultrahigh-purity helium, to minimize polyatomic interference. The instrument was calibrated, using five standard solutions $(0.5-100 \mu \mathrm{g} / \mathrm{L})$ prepared by dilution from a multi-standard solution (Periodic Table MIX 1, Sigma Aldrich $10 \mathrm{mg} / \mathrm{L}$ ). The matrix effect was evaluated through the analysis of laboratory-fortified samples, which can be considered standard solutions prepared in the sample matrix. Acceptable recoveries were obtained (77-104\%) and attesting to a negligible matrix effect. The precision of the analysis expressed as RSD \% was $<3 \%$.

\subsection{Dissolved Phase Analysis}

Total dissolved metal(loid), excluding $\mathrm{Hg}$, concentrations were determined by using an ICP-MS (NexION 350X, KED mode). The analysis was carried out, using the calibration curve method obtained by analyzing five standard solutions (range $0.2-10 \mu \mathrm{g} / \mathrm{L}$ ) prepared after dilution of a stock standard solution (Periodic Table MIX 1, Sigma-Aldrich, 10 mg/L). Analyses showed the variation coefficient $<3 \%$. The total dissolved $\mathrm{Hg}$ (DHg) determination was conducted via a pre-reduction, using $\mathrm{NH}_{2} \mathrm{OH}-\mathrm{HCl}(30 \%, 0.25 \mathrm{~mL})$, until the yellow colour disappeared, followed by a reduction with $\mathrm{SnCl}_{2} 2 \%$ (Sigma-Aldrich) in $\mathrm{HCl} 4 \%$, as in the EPA Method 1631e [22] and Atomic Fluorescence Spectrometry (AFS) detection (Mercur, Analytik Jena GmbH, Jena, Germany) coupled with a gold trap pre-concentration system. The NIST 3133 certified solution was used for calibration and ORMS-5 (CRM, Brantford, ON, Canada) was used for quality control (recovery of $105 \%$ ). The detection limit calculated on the basis of ten standard deviations of the reagent blank was $0.63 \mathrm{ng} / \mathrm{L}$ and the quantification limit (LQD) was $2.11 \mathrm{ng} / \mathrm{L}$. The precision of the analysis expressed as $\mathrm{RSD} \%$ was $<4 \%$.

\subsection{Diffusive and Benthic Flux Calculation Dissolved Phase Analysis}

The mobility of the dissolved species across the SWI can be estimated through the calculation of diffusive fluxes according to Fick's First Law [23,24]:

$$
\mathrm{F}=-\left(\phi \mathrm{Dw} / \theta^{2}\right) \delta \mathrm{C} / \delta \mathrm{x}
$$

The formula represents the instantaneous flux $(\mathrm{F})$ of a solute with concentration $\mathrm{C}$ at depth $\mathrm{x}$. The ratio $\delta \mathrm{C} / \delta \mathrm{x}$ is the concentration gradient of the chemical species between the porewaters at a depth of $1 \mathrm{~cm}$ and the overlying water; $\varphi$ is the sediment porosity; and $\theta$ is the tortuosity (dimensionless), estimated from the porosity, using the formula $\theta^{2}=1-\ln \left(\varphi^{2}\right)$ [25]. The diffusion coefficient of each metal(loid) in water (Dw) in the absence of the sediment matrix at $25{ }^{\circ} \mathrm{C}$ was obtained from Li and Gregory [26], with the exception of $\mathrm{Hg}$ for which the Dw value used is $5 \times 10^{-6} \mathrm{~cm}^{2} / \mathrm{s}$ [27]. The positive values indicate net fluxes from the porewaters to the overlying water (effluxes), whereas the negative values are representative of net influxes.

In order to interpret the tendency of the metal(loid) to be released from the sediment to the overlying water or the opposite, from the water column to the bottom sediments, during the experimental time, in situ diurnal benthic fluxes $(F)$ of dissolved species across the SWI were calculated with the method proposed by Zago et al. [28]. The same method was used by Petranich et al. [12], to calculate the daily $\mathrm{Hg}$ and $\mathrm{MeHg}$ net fluxes according to the following formula:

$$
\mathrm{F}=\left(\mathrm{C}_{\mathrm{n}+1}-\mathrm{C}_{\mathrm{n}}\right)(\mathrm{V} / \mathrm{A}) /\left(\mathrm{t}_{\mathrm{n}+1}-\mathrm{t}_{\mathrm{n}}\right)
$$


Using these methods, it was possible to determine the final metal(loid) evolution trends taking into account the concentration variability, step by step, which shows a negative or positive trend depending on the decrease or increase in metal(loid) concentrations during the experiment.

\subsection{Exploratory Multivariate Data Analysis}

A principal component analysis (PCA) was used as an unsupervised exploratory chemometric tool for the identification of relationships within variables (PC loadings and loading plot) and within samples (PC scores and score plot) [29]. A Log-transform was applied to those variables which did not show a normal distribution, and the experimental data were preprocessed through column autoscaling, in order to minimize systematic differences [30]. The CAT (Chemometric Agile Tool) package, based on the R platform (The R Foundation for Statistical Computing, Vienna, Austria) and freely distributed by Gruppo Italiano di Chemiometria (Italy) [31], was used for multivariate data processing.

\section{Results and Discussion}

\subsection{Solid Phase}

\subsubsection{Sediment Geochemistry and Enrichment Factor (EF) of Metal(loid)s}

Based on the grain-size data, sediments of both cores were rather homogeneous with depth. According to Shepard's classification [32], both sediments were prevalently silty (average $74 \%$ at VN1 and $69 \%$ at VN3), followed by sandy and clay fractions, on average $18 \%$ and $7 \%$ at $\mathrm{VN} 1$ and $25 \%$ and $5 \%$ at $\mathrm{VN} 3$, respectively [12].

The total carbon $\left(\mathrm{C}_{\text {tot }}\right)$ profiles showed a decreasing trend with depth, from 6.16 to $5.59 \%$ at $\mathrm{VN} 1$, and from 7.42 to $5.77 \%$ at VN3, whereas the organic carbon $\left(\mathrm{C}_{\text {org }}\right)$ contents varied in a narrow range (1.85-2.57\% at VN1 and $1.85-3.99 \%$ at VN3) [12]. Total nitrogen $\left(\mathrm{N}_{\text {tot }}\right)$ decreased with depth only at VN3 (from $0.51 \%$ to $0.18 \%$ ) [12]. The $\mathrm{C}_{\text {org }} / \mathrm{N}_{\text {tot }}$ molar ratio $>14$ is characteristic for organic matter of terrestrial origin [33], which is typically depleted in nitrogen and enriched in carbon. Conversely, the molar ratio $<10$ is associated with marine-derived organic matter, characterized by higher nitrogen contents [34]. In this study, $\mathrm{C}_{\text {org }} / \mathrm{N}_{\text {tot }}$ was usually $<10$, thus indicating the marine origin of the organic matter. Only the last two levels at VN3 showed higher $\mathrm{C}_{\text {org }} / \mathrm{N}_{\text {tot }}$ values of 10.2 and 17.4, respectively [12].

As an additional chemometric support to the traditional data interpretation, PCA was performed on total and labile metal(loid) concentrations in sediments to better underline differences between the two investigated sites and among depth levels (Figure 2). The two investigated sites are clearly distinguished in the PCA output, and, generally, slightly higher concentrations of metal(loid)s were found at site VN3 where $\mathrm{Cd}, \mathrm{Cr}, \mathrm{Cu}, \mathrm{Fe}, \mathrm{Ni}, \mathrm{Pb}$, $\mathrm{V}$ and $\mathrm{Zn}$ reached maximum values in the first level of sediments (Figure 2 and Table 1). The vertical profiles of $\mathrm{Cd}, \mathrm{Cu}, \mathrm{Cr}, \mathrm{Fe}, \mathrm{Mn}, \mathrm{Ni}, \mathrm{Pb}, \mathrm{V}$ and $\mathrm{Zn}$ contents at VN1 showed rather constant values with increasing depth, thus suggesting a common source of these metal(loid)s (Supplementary Materials Figure S1). Arsenic and $\mathrm{Hg}$ varied in a relatively narrow range decreasing with depth. Moreover, at site VN3, the metal(loid) trends were pretty constant with depth, and only As, $\mathrm{Hg}$ and Mn showed increasing values (Table 1).

To assess whether "anomalous" metal(loid) contributions are present in the sediments, metal(loid) concentrations (M) were normalized to a grain-size proxy, i.e., a normalizing element $(\mathrm{N})$, and compared to the same ratio from the local baseline, to obtain the Enrichment Factor $\left(\mathrm{EF}=[\mathrm{M} / \mathrm{N}]_{\text {sample }} /[\mathrm{M} / \mathrm{N}]_{\text {baseline }}\right)$. In this study, $\mathrm{Al}$ was chosen as the normalizing element, since it has been proved that it is essentially lithogenic in the sediments of the Northern Adriatic [35]. The $\mathrm{M} / \mathrm{N}$ ratio for the baseline was calculated from the average concentrations obtained from the deepest three levels $(49-50,69-70$ and 95-96 cm) of a $1 \mathrm{~m}$-long sediment core collected in the Grado Lagoon (G4, [36]) near the Val Noghera fish farm. A value of unity denotes no enrichment or depletion relative to the local background. 

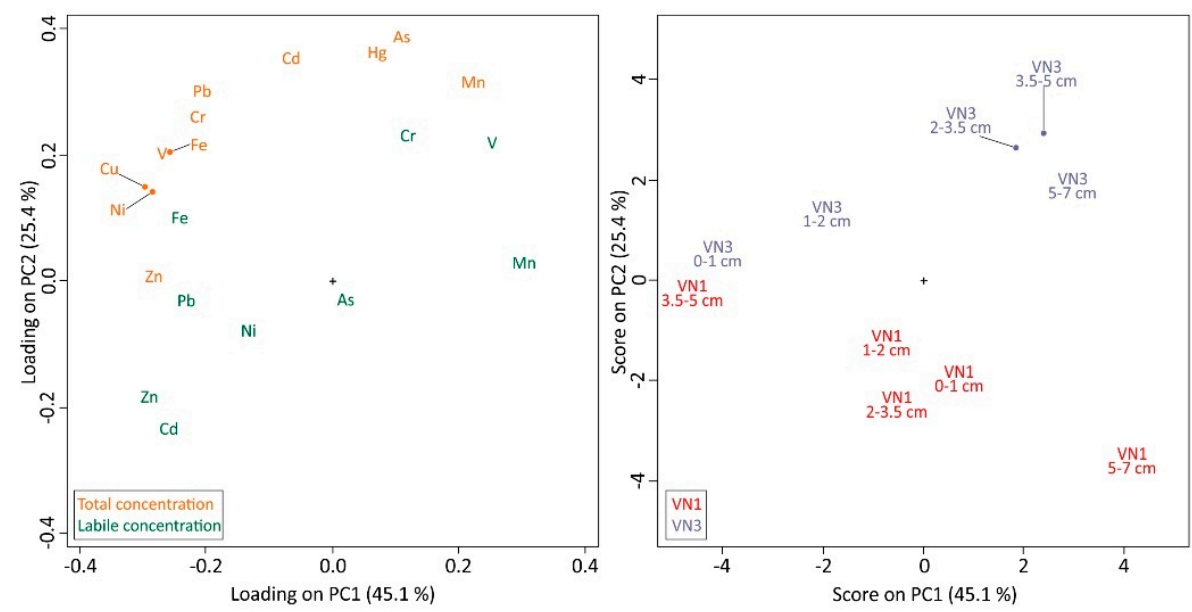

Figure 2. Score and loading plots resuming the results of principal component analysis (PCA) performed on total and labile metal(loid) concentrations is sediments at sites VN1 and VN3.

Table 1. Metal(loid) concentrations in each level of the VN1 and VN3 sediment cores.

\begin{tabular}{|c|c|c|c|c|c|c|c|c|c|c|c|c|c|}
\hline \multirow{2}{*}{ Site } & Level & Al & $\mathrm{Fe}$ & As & $\mathrm{Cd}$ & $\mathrm{Cr}$ & $\mathrm{Cu}$ & $\mathrm{Hg}$ & Mn & $\mathrm{Ni}$ & $\mathrm{Pb}$ & V & $\mathrm{Zn}$ \\
\hline & $(\mathrm{cm})$ & $\%$ & $\%$ & $\mu \mathrm{g} / \mathrm{g}$ & $\mu \mathrm{g} / \mathrm{g}$ & $\mu \mathrm{g} / \mathrm{g}$ & $\mu \mathrm{g} / \mathrm{g}$ & $\mu \mathrm{g} / \mathrm{g}$ & $\mu \mathrm{g} / \mathrm{g}$ & $\mu \mathrm{g} / \mathrm{g}$ & $\mu \mathrm{g} / \mathrm{g}$ & $\mu \mathrm{g} / \mathrm{g}$ & $\mu \mathrm{g} / \mathrm{g}$ \\
\hline \multirow{5}{*}{ VN1 } & $0-1$ & 7.03 & 5.71 & 7.62 & 1.64 & 84.8 & 25.9 & 5.10 & 404 & 55.7 & 32.6 & 78.3 & 85.0 \\
\hline & $1-2$ & 8.88 & 6.78 & 7.73 & 1.94 & 83.7 & 27.4 & 4.19 & 359 & 57.0 & 37.4 & 81.1 & 87.0 \\
\hline & $2-3.5$ & 7.26 & 6.19 & 6.44 & 1.89 & 78.8 & 23.6 & 3.62 & 340 & 55.2 & 36.8 & 77.7 & 100 \\
\hline & $3.5-5$ & 8.74 & 6.93 & 5.93 & 2.13 & 90.3 & 30.7 & 3.20 & 313 & 64.9 & 41.2 & 93.4 & 121 \\
\hline & $5-7$ & 6.76 & 4.99 & 6.47 & 1.90 & 74.0 & 19.0 & 2.15 & 396 & 47.6 & 32.9 & 67.2 & 72.2 \\
\hline \multirow{5}{*}{ VN3 } & $0-1$ & 5.34 & 7.18 & 8.29 & 2.22 & 86.5 & 32.8 & 4.20 & 366 & 60.2 & 43.2 & 87.1 & 95.4 \\
\hline & $1-2$ & 6.18 & 6.55 & 11.2 & 2.29 & 85.3 & 29.9 & 5.11 & 444 & 58.4 & 43.1 & 86.3 & 93.4 \\
\hline & $2-3.5$ & 6.86 & 6.82 & 12.3 & 2.26 & 83.1 & 25.4 & 6.87 & 497 & 54.8 & 40.9 & 80.0 & 85.9 \\
\hline & $3.5-5$ & 7.86 & 5.97 & 11.5 & 2.39 & 85.7 & 24.3 & 5.98 & 512 & 54.2 & 39.8 & 78.5 & 80.7 \\
\hline & $5-7$ & 6.87 & 6.09 & 10.7 & 2.00 & 84.8 & 24.6 & 5.23 & 529 & 57.4 & 37.1 & 83.5 & 86.4 \\
\hline
\end{tabular}

According to the five degrees of contamination proposed by Sutherland [37], the highest EF values were found at site VN3 (Supplementary Materials Table S1), especially for $\mathrm{Cd}$ and $\mathrm{Hg}$, which showed a significant enrichment $(\mathrm{EF}=5-20)$, and for $\mathrm{Fe}$, which showed a moderate enrichment $(E F=2-5)$, but only in the $0-1 \mathrm{~cm}$ level (2.27). Cadmium and $\mathrm{Hg}$ were significantly enriched also in core VN1, but with EF values lower than VN3. The significant enrichment of $\mathrm{Hg}$ is due to the legacy of 500 years of the historical mining activity at Idrija (NW Slovenia) [38], whereas Cd, as well as the minimal enrichment $(\mathrm{EF}<2)$ observed for $\mathrm{Fe}, \mathrm{Pb}$ and $\mathrm{Zn}$ at both sites, could be associated with the more recent anthropogenic inputs from several local sources, mainly industrial and agricultural activities located inland. Among them, the industrial site of Torviscosa represents the main source of concern [11], being the primary chemical stress for the lagoon environment. In addition to $\mathrm{Hg}$, which was discharged from 1949 to 1984 into the Aussa-Corno River system from the decommissioned chlor-alkali plant of Torviscosa, the occurrence of other metal(loid)s ( $\mathrm{Cd}, \mathrm{Zn}, \mathrm{As}, \mathrm{Pb}$ and $\mathrm{Cu}$ ) could be related to several industrial activities that took place in this site [11]. Moreover, hot-spot contamination sources due to industrial activities, as well as waste disposal, have been identified at the industrial area of Porto Nogaro harbour [11]. Anthropogenic metal(loid)s successively accumulated in the centralwestern sector of the lagoon, included in this fish farm, before the construction of the embankments. Moreover, we cannot discard that these inputs could be partially associated with the terrigenous supplies of the Isonzo River flowing into the Gulf of Trieste. Here, the main anticlockwise circulation system and the longshore currents are responsible for the transport of fluvial sediments to the eastern sector of the lagoon through the tidal 
inlets [39]. No enrichment ( $\mathrm{EF} \approx 1)$ for $\mathrm{As}, \mathrm{Cr}, \mathrm{Cu}, \mathrm{Mn}, \mathrm{Ni}$ and $\mathrm{V}$ was observed at either site (Supplementary Materials Table S1).

\subsubsection{Labile Fraction of Metal(loid)s in Sediments}

The weak extraction did not depict a noticeable difference between sites and depth levels (Table 2), excluding Mn at both sites (35.3\% and $28.34 \%$ of the total content at VN1 and $\mathrm{VN} 3$, respectively), as well as $\mathrm{Cr}$ and $\mathrm{Ni}$, in the level $3.5-5 \mathrm{~cm}$ at $\mathrm{VN} 3(19.9 \%$ and $14.4 \%$ of the total content, respectively) (Figure 2).

Table 2. Labile fraction (expressed in \%) of metal(loid)s in sediments at sites VN1 and VN3. The abbreviation "u. f." means unavailable form and "LOD" means limit of detection.

\begin{tabular}{|c|c|c|c|c|c|c|c|c|c|c|c|c|c|}
\hline \multirow{2}{*}{ Site } & \multirow{2}{*}{$\begin{array}{l}\text { Level } \\
(\mathrm{cm})\end{array}$} & Al & As & $\mathrm{Cd}$ & $\mathrm{Cr}$ & $\mathrm{Cu}$ & Fe & $\mathrm{Hg}$ & Mn & $\mathrm{Ni}$ & $\mathbf{P b}$ & $\mathbf{V}$ & $\mathrm{Zn}$ \\
\hline & & \multicolumn{12}{|c|}{ Labile Fraction (\%) } \\
\hline \multirow{5}{*}{ VN1 } & $0-1$ & 0.09 & 1.59 & 9.96 & u. f. & u. f. & 0.01 & u. f. & 35.2 & 2.95 & 0.18 & 0.05 & 9.30 \\
\hline & $1-2$ & 0.09 & 0.89 & 8.86 & u. f. & u. f. & 0.00 & u. f. & 34.1 & 3.69 & u. f. & 0.03 & 12.2 \\
\hline & $2-3.5$ & $\begin{array}{c}< \\
\text { LOD }\end{array}$ & 0.85 & 9.30 & u. $\mathrm{f}$. & u. f. & 0.04 & u. f. & 36.1 & 3.71 & 0.04 & 0.03 & 11.9 \\
\hline & $3.5-5$ & 0.02 & 1.33 & 8.63 & u. f. & u. f. & 0.11 & u. f. & 33.2 & 4.27 & 0.12 & 0.03 & 10.6 \\
\hline & $5-7$ & 0.03 & 1.42 & 6.77 & u. f. & u. f. & 0.01 & u. f. & 37.9 & 2.32 & u. f. & 0.19 & 4.55 \\
\hline \multirow{5}{*}{ VN3 } & $0-1$ & 0.08 & 1.30 & 7.91 & u. f. & u. f. & 0.37 & u. f. & 28.2 & 3.86 & 0.28 & 0.03 & 13.6 \\
\hline & $1-2$ & 0.06 & 0.63 & 7.63 & u. f. & u. f. & 0.11 & u. f. & 28.4 & 3.17 & 0.06 & 0.02 & 12.2 \\
\hline & $2-3.5$ & 0.10 & 0.51 & 4.45 & u. f. & u. f. & 0.00 & u. f. & 25.4 & 0.34 & u. f. & 0.22 & 0.34 \\
\hline & $3.5-5$ & 0.08 & 0.85 & 4.62 & 19.9 & u. f. & 0.08 & u. f. & 29.6 & 14.4 & 0.04 & 0.88 & 1.44 \\
\hline & 5-7 & 0.11 & 0.80 & 4.62 & 0.07 & u. f. & 0.00 & u. f. & 30.1 & 0.43 & u. f. & 1.23 & 0.37 \\
\hline
\end{tabular}

In general, the labile fraction of metal(loid)s decreased in the following order: $\mathrm{Mn}>$ $\mathrm{Zn}>\mathrm{Cd}>\mathrm{Ni}>\mathrm{As}, \mathrm{Fe}, \mathrm{V}$ and $\mathrm{Pb}$ (in some levels). Chromium, $\mathrm{Cu}$ and $\mathrm{Hg}$ were not shown to be associated with the labile fraction ( $0 \%$ of the total content), whereas $\mathrm{As}, \mathrm{Fe}, \mathrm{V}$ and in some levels $\mathrm{Pb}$ showed very low mobility $(0.04-1.59 \%)$, Ni showed a scarce mobility (0.34-4.27\%), excluding the level $3.5-5 \mathrm{~cm}$ at VN3 (14.4\%), and $\mathrm{Zn}$ and $\mathrm{Cd}$ showed a limited mobility (0.34-13.6\% and 4.45-9.96\% for $\mathrm{Zn}$ and $\mathrm{Cd}$, respectively). Only the labile fraction of Mn was found to be the highest (25.4-37.9\% of the total content), especially at VN1.

Mineralogy and grain-size, chemical speciation, $\mathrm{pH}$, Eh and organic matter are important factors influencing the accumulation and availability of metal(loid)s in sediments [40] and they affect their remobilisation and partitioning between solid and dissolved phases. It is known that the reduction of Fe and Mn oxy-hydroxides can favor the release of some metal(loid)s previously associated with sediment particles to porewaters [41].

In anoxic conditions, metal(loid)s can also form insoluble sulphides and precipitate in the sediment [42]. In our study, the negative Eh values in sediments and the high $\mathrm{H}_{2} \mathrm{~S}$ concentrations in porewaters (up to nearly $1200 \mu \mathrm{mol} / \mathrm{L}$, [12]) could have contributed to the formation of stable complexes with sulphides [43], since the mobility of the majority of metal(loid)s was found to be scarce or null. The notable $\mathrm{Cd}$, Ni and $\mathrm{Zn}$ partitioning in the labile fraction could be attributed to their bonding onto Mn hydrate complex, as indicated by the high percentage of Mn labile fraction (Table 2). Its reduction might have affected the metal remobilisation and redistribution [41]. A value of unity denotes no enrichment or depletion relative to the local background. The low percentages of the labile fraction, considered as an operational parameter subjected to different non-selective extraction procedures and the presence of various phases [44], seem to limit the role of sediments as a secondary contamination source. In perturbed sediments, the changes of the redox conditions might partially favor the release of metal(loid)s to the porewaters and the water column. 


\subsection{Dissolved Phase}

3.2.1. Metal(loid) Concentration Profiles in Porewaters and Distribution Coefficient $\left(K_{\mathrm{D}}\right)$

Aluminum, $\mathrm{Cd}, \mathrm{Cu}, \mathrm{Fe}, \mathrm{Pb}$ and $\mathrm{Zn}$ concentrations in porewaters, at $\mathrm{VN} 3$ were higher than those found at VN1 (Figure 3). At site VN1, metal(loid) concentrations varied with depth (excluding $\mathrm{Al}$ which remained rather constant) and almost all (As, $\mathrm{Cd}, \mathrm{Fe}, \mathrm{Hg}, \mathrm{Mn}$, $\mathrm{Pb}$ and $\mathrm{V})$ showed a maximum in the first level $(0-1 \mathrm{~cm})$ and then a decrease with depth, except for As and $\mathrm{V}$, which conversely increased. A similar trend was observed for $\mathrm{Hg}, \mathrm{Fe}$, $\mathrm{Mn}, \mathrm{Cr}$ and Ni. Mercury, Fe and Mn (Figures 3 and 4 ) showed the maximum concentrations in the first level $(0-1 \mathrm{~cm})$ whereas $\mathrm{Cr}$ and $\mathrm{Ni}$ in the second level $(1-2 \mathrm{~cm})$. Similarly, in the porewaters of $\mathrm{VN} 3$, the maximum occurred in the first $2 \mathrm{~cm}$.
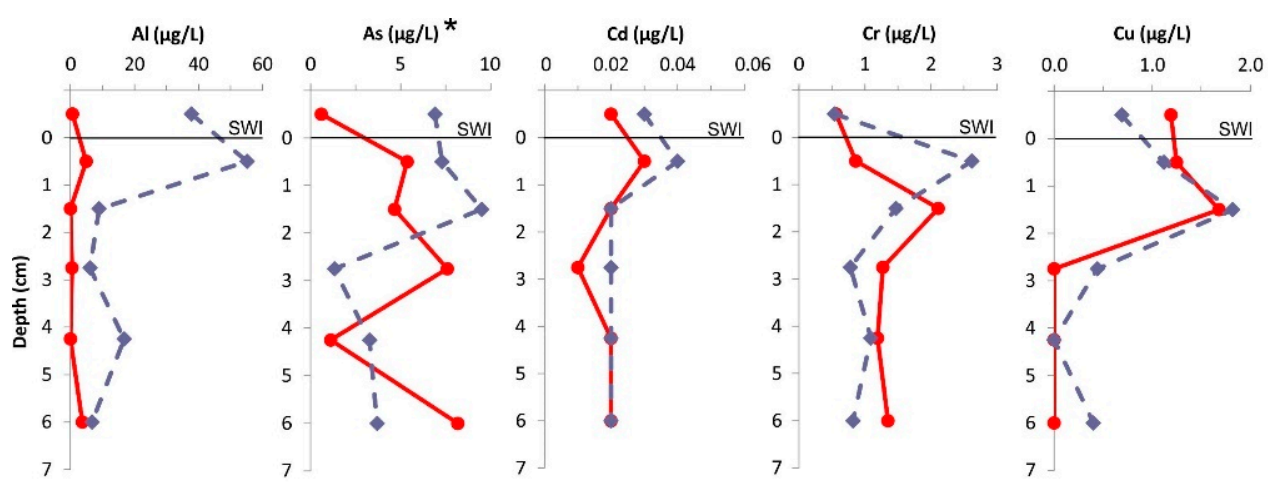

Legend: $\multimap$ VN1 $\multimap-$ VN3
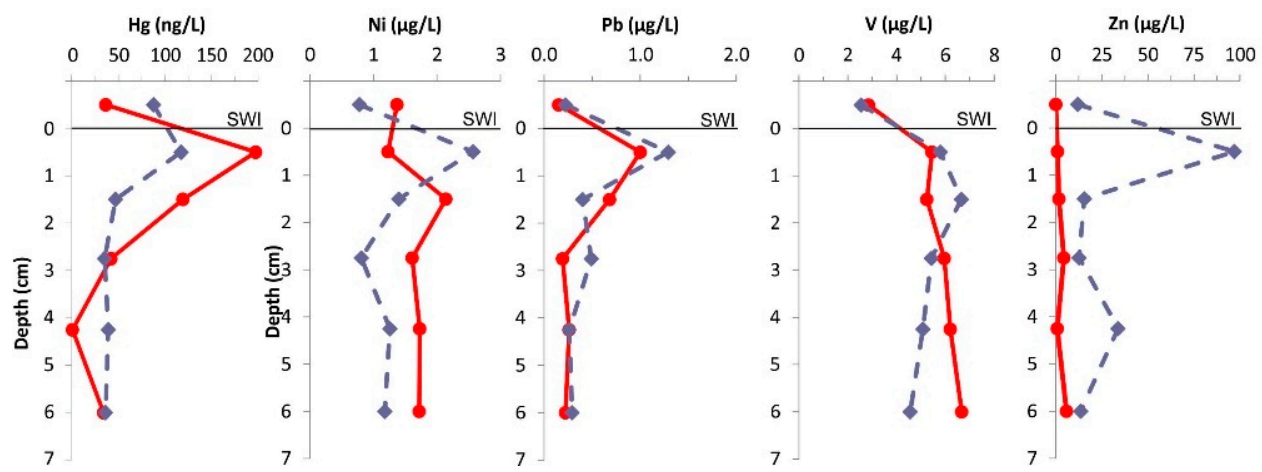

Figure 3. Vertical profiles of metal(loid)s in porewaters at both investigated sites. ${ }^{*}$ ) For a better comparison of the results with those obtained for site VN3, the values of As in VN1 were graphically divided by a factor of 10 .
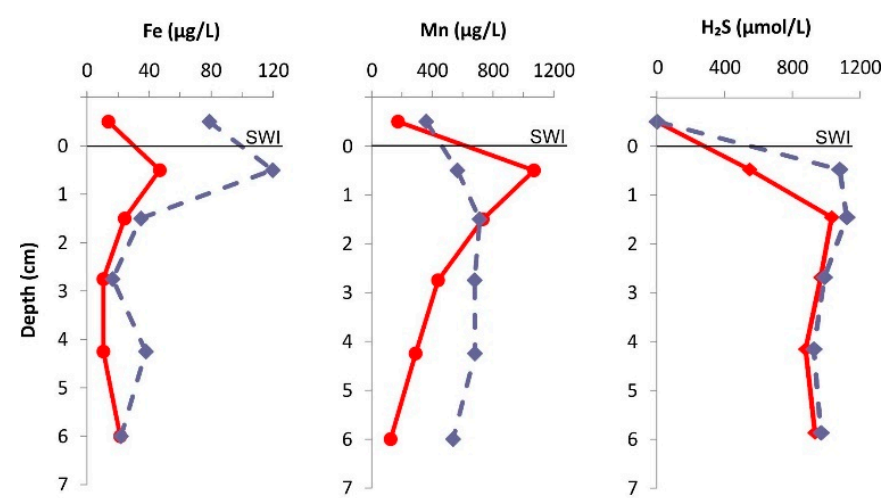

Legend: $\multimap$ VN1 $\longrightarrow \bullet-\mathrm{VN} 3$

Figure 4. Comparison between vertical profiles of dissolved $\mathrm{Fe}, \mathrm{Mn}$ and $\mathrm{H}_{2} \mathrm{~S}$ [12] in porewaters in the two selected sites, VN1 and VN3. 
According to the early diagenetic sequence [45], the approximate location of $\mathrm{Mn}$ reduction should be found above the Fe reduction zone, but this never occurred in any site; the Mn reduction zone is below that of $\mathrm{Fe}$ at $\mathrm{VN} 3$, whereas they are overlapped at the depth of $0-1 \mathrm{~cm}$ at VN1 (Figure 4). However, the marked enrichment of Fe, Mn and $\mathrm{H}_{2} \mathrm{~S}$ in the upper levels $(0-1$ and $1-2 \mathrm{~cm})$ at both sites, where the Fe-Mn oxy-hydroxides and sulphate reduction zones seem to overlap, did suppose the presence of a redox-cline at the top of the sedimentary sequence. Since Fe and $\mathrm{Mn}$ concentrations decreased in parallel with $\mathrm{Cu}, \mathrm{Cr}, \mathrm{Ni}, \mathrm{Hg}, \mathrm{Pb}$ and $\mathrm{Zn}$, whereas the $\mathrm{H}_{2} \mathrm{~S}$ concentrations remain high until the last layer $(933 \mu \mathrm{mol} / \mathrm{L}$ at VN1 and $968 \mu \mathrm{mol} / \mathrm{L}$ at VN3), as well as high total sulphur contents in the sedimentary matrix [12], both reactions among $\mathrm{H}_{2} \mathrm{~S}$ and metal(loid)s, followed by precipitation, and the formation of insoluble compounds (e.g., sulphides) or complexes with very low solubility [43], could explain these decreasing trends.

The vertical profiles of the metal(loid) concentrations were variable in porewaters but relatively constant in sediments (Supplementary Materials Figure S1), and no relationship was identified between the two phases.

Factors such as $\mathrm{H}_{2} \mathrm{~S}$ concentrations and metal speciation could be important in the partitioning of metal(loid)s between both phases in these strong reductive sediments characterized by low Eh, varying from -417 to $-439 \mathrm{mV}$, at VN1, and from -367 to $-401 \mathrm{mV}$, at VN3.

LogK $K_{D}$ values, describing the partitioning of metal(loid)s between solid and dissolved phase [41,46,47], are rather constant with depth at both sites. Only the $\log \mathrm{K}_{\mathrm{D}}$ of $\mathrm{Cd}, \mathrm{Hg}, \mathrm{Pb}$ and $\mathrm{Zn}$ slightly vary at $\mathrm{VN} 1$ and $\mathrm{Al}, \mathrm{Cr}, \mathrm{Fe}$ and $\mathrm{Pb}$ vary at VN3 (Supplementary Materials Table S2). The highest mean values were found for $\mathrm{Al}(7.55 \pm 4.15), \mathrm{Fe}(6.50 \pm 0.30), \mathrm{Hg}$ $(5.26 \pm 0.94)$ and $\mathrm{Pb}(4.98 \pm 0.34)$ at $\mathrm{VN} 1$, and $\mathrm{Al}(6.71 \pm 0.43), \mathrm{Cd}(4.99 \pm 0.14)$ and $\mathrm{Fe}$ $(6.26 \pm 0.32)$ at VN3. Since no significant differences were detected between the two sites (Supplementary Materials Table S2), a steady equilibrium between the dissolved and the solid phase was supposed.

Comparing our results with previous research, the $\log \mathrm{K}_{\mathrm{D}}$ values for $\mathrm{Hg}(5.26 \pm 0.94$ at VN1 and $4.86 \pm 0.15$ at VN3) are comparable to those found in Taranto's Mar Piccolo $(5.4 \pm 0.2$ and $5.3 \pm 0.1)$ which is contaminated by $\mathrm{Hg}$ and other trace metals of industrial origin [23]. Our values were also found to be similar to those estimated in two marinas (5.30 \pm 0.88 and $4.95 \pm 0.88)$ of the Northern Adriatic [24].

$\log \mathrm{K}_{\mathrm{D}}$ of $\mathrm{Cd}, \mathrm{Cr}, \mathrm{Cu}, \mathrm{Fe}$ and Ni were usually found to be the highest; $\mathrm{As}, \mathrm{Hg}, \mathrm{Mn}$ and $\mathrm{Pb}$ showed similar values; and $\mathrm{Zn}$ was found to be the lowest. Considering other studies, $\log \mathrm{K}_{\mathrm{D}}$ for $\mathrm{Zn}(4.06 \pm 0.46$ at $\mathrm{VN} 1$ and $3.56 \pm 0.37$ at VN3) were similar to those found in the Galveston Bay, Texas $(3.9 \pm 0.3,[41])$ and in the Kalloni Bay, Greece $(3.6 \pm 0.3,[48])$, whereas the $\log \mathrm{K}_{\mathrm{D}}$ for $\mathrm{Fe}(6.50 \pm 0.30$ at VN1 and $6.26 \pm 0.32$ at VN3) was found to be the highest ( $4.3 \pm 0.5$ and $5.3 \pm 0.8$, respectively). Only the $\log K_{D}$ values for $\mathrm{Mn}(2.94 \pm 0.36$ at VN1 and $2.87 \pm 0.08$ at VN3) were higher than those of the Galveston Bay (2.0 \pm 0.3$)$ but lower than in the Kalloni Bay $(4.2 \pm 0.8)$. The rather constant trend with depth at both sites (Supplementary Materials Table S2), as well as the high $\log \mathrm{K}_{\mathrm{D}}$ values estimated for $\mathrm{Al}$, $\mathrm{Fe}$ and $\mathrm{Hg}$, likely reflects the scarce mobility of metal(loid)s from the fish farm sediments to the water column, as also confirmed by the results obtained by the weak extraction procedure (Table 2).

\subsubsection{Metal(loid)s in the Benthic Chamber}

The two sites experimented different behavior, especially in terms of dissolved oxygen $\left(\mathrm{O}_{2}\right)$ concentrations and Eh values in the benthic chamber. Site VN1 showed $\mathrm{O}_{2}$ levels $(1.97-3.33 \mathrm{mg} / \mathrm{L})$ and positive Eh values $(8.7-87 \mathrm{mV})$. Conversely, VN3 was characterized by anoxia $\left(\mathrm{O}_{2}<0.1 \mathrm{mg} / \mathrm{L}\right)$ and reducing conditions, where Eh values were clearly negative, ranging between -356 and $-394 \mathrm{mV}$. This wide dissimilarity could be attributed to the location of the sampling sites in the fish farm in terms of hydrodynamics, since the water circulation is driven by the wind and water exchange with the open lagoon only occurs through the sluice gates [12]. 
The highest metal(loid) concentrations during the benthic chamber experiments were found at site VN1, excluding As, $\mathrm{Cu}, \mathrm{Hg}$ and $\mathrm{Mn}$ which were higher at VN3 (Figure 5). Excluding $\mathrm{As}, \mathrm{Mn}, \mathrm{Pb}$ and $\mathrm{V}$, which remained constant during the experiment at $\mathrm{VN} 1$, the maximum values generally occurred at $T_{1}(2 \mathrm{~h})$ and $T_{2}(4 \mathrm{~h})$ samplings and then decreased until $\mathrm{T}_{4}(8 \mathrm{~h})$. Only $\mathrm{Zn}$ showed an increase until the end of the experiment. These trends may be justified by the opposite behavior of dissolved $\mathrm{O}_{2}$ and Eh (Figure 5), since the precipitation of metal(loid)s in oxidized form, likely associated with Fe oxides, would have occurred. The increase of $\mathrm{O}_{2}$ at $\mathrm{VN} 1$ suggests that the dissolved $\mathrm{O}_{2}$ production by photosynthesis prevailed over the microbial respiration. On the contrary at VN3, where nearly all metal(loid)s remained rather constant, $\mathrm{Cu}$ slightly varied over time and $\mathrm{Pb}$ and $\mathrm{Zn}$ showed a maximum at $\mathrm{T}_{1}(2 \mathrm{~h})$ and $\mathrm{T}_{3}(6 \mathrm{~h})$, respectively (Figure 5). This can be a consequence of the permanent reducing conditions that characterised this site during the experiment. Indeed, the constant anoxia has likely prevented the alternation of the precipitation and dissolution processes, which usually influence the physicochemical form of the metal(loid)s, favoring the presence of the dissolved form, and, thus, eliminating the variability that characterised the behavior of metal(loid)s.
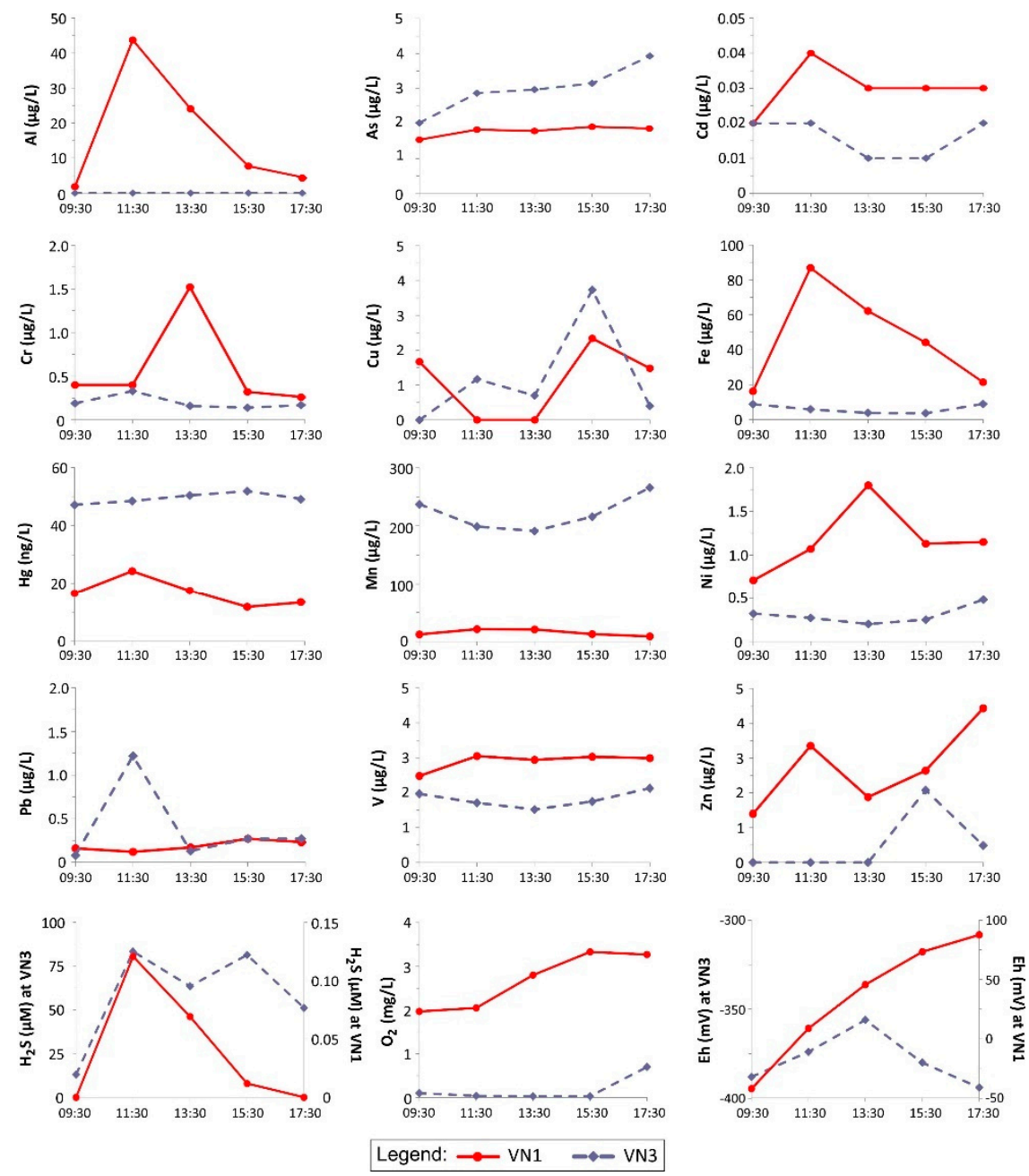

Figure 5. Concentrations of metal(loid)s, hydrogen sulphide $\left(\mathrm{H}_{2} \mathrm{~S}\right.$, [12]), dissolved oxygen and Eh values vs. time in the benthic chamber at VN1 and VN3.

\subsubsection{Diffusive and Benthic Fluxes at the SWI}

Regarding the diffusive fluxes, a net efflux involved most of the studied metal(loid)s (Table 3), especially at VN3. The influxes were only estimated in the case of $\mathrm{Ni}\left(-0.53 \mu \mathrm{g} / \mathrm{m}^{2} \mathrm{~d}\right)$ and $\mathrm{Zn}\left(-23.7 \mu \mathrm{g} / \mathrm{m}^{2} \mathrm{~d}\right)$ at VN1. Remarkable Mn efflux was found at both sites (3415 and 
$803 \mu \mathrm{g} / \mathrm{m}^{2} \mathrm{~d}$ at VN1 and VN3, respectively), reflecting its elevated labile concentration in the corresponding sediment (Table 2). Conversely, high effluxes were shown by Fe and As at VN1 and $\mathrm{Zn}$ at VN3 (Table 3), possibly due to the corresponding low concentrations found in the supernatant waters, rather than their very low labile fraction (Table 2). Comparing our results with those of Taranto's Mar Piccolo [23], we saw that our fluxes were higher, up three orders of magnitude in the case of As (240 and $0.99 \mu \mathrm{g} / \mathrm{m}^{2} \mathrm{~d}$, respectively) and Fe (167 and $0.03 \mu \mathrm{g} / \mathrm{m}^{2}$ d). This indicates intense recycling at the SWI and release to the water column. However, from the comparison with diffusive fluxes reported for two marinas [24], it appears that $\mathrm{Cd}, \mathrm{Cr}$ and $\mathrm{Ni}$ resulted, whereas $\mathrm{Cu}$ and especially $\mathrm{Hg}$ showed much lower effluxes $\left(0.44\right.$ and $0.08 \mu \mathrm{g} / \mathrm{m}^{2}$ $\mathrm{d}$ at VN1 and VN3, respectively, vs. 932,238 and $92.6 \mu \mathrm{g} / \mathrm{m}^{2} \mathrm{~d}$ at SL, SR1 and SR2, respectively). The diffusive fluxes of $\mathrm{H}_{2} \mathrm{~S}$ were found to be the highest in comparison with those of other studies, up to four [24] and five [49] times higher, more evident at VN3, where $\mathrm{H}_{2} \mathrm{~S}$ efflux was found to be almost twice that with respect to VN1.

Table 3. Comparison among diffusive fluxes of metal(loid)s (expressed in $\mu \mathrm{g} / \mathrm{m}^{2} \mathrm{~d}$ ) and $\mathrm{H}_{2} \mathrm{~S}$ (expressed in $\mathrm{mmol} / \mathrm{m}^{2} \mathrm{~d}^{1}$, [12]) estimated at VN1 and VN3 (SLO: Slovenia; ITA: Italy; n.d.: not determined).

\begin{tabular}{|c|c|c|c|c|c|c|c|c|c|c|c|c|c|}
\hline \multirow[t]{2}{*}{ Site } & \multicolumn{12}{|c|}{ Diffusive Fluxes $\left(\mu \mathrm{g} / \mathrm{m}^{2} \mathrm{~d}\right)$} & \multirow{2}{*}{$\begin{array}{c}\left(\mathrm{mmol} / \mathrm{m}^{2}\right. \\
\mathrm{d})\end{array}$} \\
\hline & Al & As & $\mathrm{Cd}$ & $\mathrm{Cr}$ & $\mathrm{Cu}$ & $\mathrm{Hg}$ & $\mathrm{Fe}$ & Mn & $\mathrm{Ni}$ & $\mathrm{Pb}$ & $\mathbf{V}$ & Zn & \\
\hline $\begin{array}{l}\text { VN1 } \\
\text { (this } \\
\text { study) }\end{array}$ & 13.3 & 240 & 0.04 & 0.99 & 0.24 & 0.44 & 132 & 3415 & -0.53 & 4.44 & 8.62 & -23.7 & $28.6[12]$ \\
\hline $\begin{array}{l}\text { VN3 } \\
\text { (this } \\
\text { study) }\end{array}$ & 55.1 & 2.06 & 0.04 & 7.01 & 1.79 & 0.08 & 167 & 803 & 6.90 & 5.74 & 11.0 & 345 & $55.5[12]$ \\
\hline $\begin{array}{c}\text { SL, } \\
\text { Lucija } \\
\text { (SLO) } \\
{[23]}\end{array}$ & n.d. & 21.0 & 0.02 & 5.47 & 8.05 & 932 & 0.03 & 499 & 6.36 & -52.2 & n.d. & -3.36 & 0.006 \\
\hline $\begin{array}{c}\text { SR-1, } \\
\text { San } \\
\text { Rocco } \\
\text { (ITA) } \\
\text { [23] }\end{array}$ & n.d. & 50.4 & 0.00 & 0.21 & -17.7 & 283 & 1.47 & 40.9 & -8.27 & -62.7 & n.d. & -90.7 & n.d. \\
\hline $\begin{array}{c}\text { SR-2, } \\
\text { San } \\
\text { Rocco } \\
\text { (ITA) } \\
\text { [23] }\end{array}$ & n.d. & 11.7 & -0.03 & 0.56 & -157 & 92.6 & 0.97 & 6980 & 1.11 & 4.75 & n.d. & 37.2 & 0.001 \\
\hline $\begin{array}{c}\mathbf{1} \mathbf{E}, \\
\text { Taranto } \\
\text { (ITA) } \\
{[22]}\end{array}$ & n.d. & 0.99 & 0.00 & 0.01 & 0.14 & 1.50 & 0.03 & 78.0 & 0.02 & -0.13 & -0.61 & -2.87 & -0.0002 \\
\hline $\begin{array}{c}\mathbf{1} \mathbf{I}, \\
\text { Taranto } \\
\text { (ITA) } \\
\text { [22] }\end{array}$ & n.d. & 1.31 & 0.03 & 0.02 & -0.08 & 12.1 & 0.00 & 47.9 & 0.04 & 0.20 & -0.92 & -0.38 & 0.0021 \\
\hline
\end{tabular}

Almost all the benthic fluxes were found to be positive, even reaching thousands of $\mu \mathrm{g} / \mathrm{m}^{2} \mathrm{~d}$ (Fe at VN1 and Mn at VN3), and therefore indicative of efflux of metal(loid)s from the sediment to the overlying water column (Table 4). In particular, this occurred at VN3, where effluxes of all metal(loid)s—excluding $\mathrm{Cr}$, which showed an influx - could be explained by the anoxic conditions that characterised this site, as also confirmed by the highest efflux estimated for $\mathrm{H}_{2} \mathrm{~S}\left(11,987 \mu \mathrm{mol} / \mathrm{m}^{2} \mathrm{~d}\right)$. At site $\mathrm{VN1}$, not only $\mathrm{Cr}$ but also $\mathrm{Cu}$, 
$\mathrm{Hg}$ and Mn showed influxes, which could be the consequence of the immobilisation of $\mathrm{Mn}$ and, in parallel, of the other involved metal(loid)s. However, the highest benthic effluxes, except $\mathrm{As}$ and $\mathrm{Pb}$, were observed at this oxic site, $\mathrm{VN1}$, thus indicating a major release from sediment to water column of $\mathrm{Al}, \mathrm{Fe}, \mathrm{Ni}, \mathrm{V}, \mathrm{Cd}$ and $\mathrm{Zn}$. These benthic fluxes could be largely governed by the intense bioturbation, mostly by polychaetes [50], occurred at this site as already observed in the Thau Lagoon along the French Mediterranean coast [51]. The effluxes of $\mathrm{Cu}, \mathrm{Pb}$ and $\mathrm{Hg}$, and especially $\mathrm{As}$ and $\mathrm{Mn}$, were estimated as being higher at VN3 than VN1, and they could be related to the association with Mn-oxides. In particular, Mn appears to be very important in the sediment redox processes [48,51] found in a high percentage of the labile fraction as oxide and hydroxide in the thin oxic SWI onto which other metals can be bonded or adsorbed. In anoxic conditions, Mn, which shows a very high efflux, is reduced and released in dissolved form, together with other metal(loid)s, to the overlying water column. Similarly, As, which is known to be involved in the redox processes [52], showed the highest efflux at this anoxic site VN3 (Table 4). Conversely, the lower influx of $\mathrm{Cr}$ at VN3 could be due to its lower solubility than in oxic site VN1 [53] and/or complexing with organic ligands [43]. Moreover, the behavior of metal(loid)s also depends on microbial activity [45], which degrades organic matter that acts as a complexing agent for many elements. This can be an additional reason for higher effluxes of other metal(loid)s in oxic conditions at VN1. Moreover, some contribution to the increase of the dissolved metal(loid) concentrations in the benthic chamber could be due to the resuspension of sediment as a consequence of the benthic chamber deployment [54]. In the case of $\mathrm{Al}$, it was not possible to calculate the benthic flux at the anoxic site, $\mathrm{VN} 3$, since it is present in sediment and in porewaters but not in the benthic chamber. Aluminum is a conservative element of the sedimentary matrix and was not influenced by the changes of redox conditions.

Table 4. Comparison among benthic fluxes of metal(loid)s and $\mathrm{H}_{2} \mathrm{~S}$ [12] estimated at VN1 and VN3 and those re-calculated in two marinas (SL, Lucija Marina (SLO), and SR1, San Rocco Marina (ITA), [23]), using the same method used in this study [27]. The abbreviation "n.d." indicates "not determined".

\begin{tabular}{|c|c|c|c|c|c|c|c|c|c|c|c|c|c|}
\hline \multicolumn{14}{|c|}{ Daily Benthic Fluxes } \\
\hline & & & & & & $g / m^{2} d$ & & & & & & & $\mu \mathrm{mol} / \mathrm{m}^{2} \mathrm{~d}$ \\
\hline Site & Al & As & $\mathrm{Cd}$ & $\mathrm{Cr}$ & $\mathrm{Cu}$ & $\mathrm{Fe}$ & $\mathrm{Hg}$ & Mn & $\mathrm{Ni}$ & $\mathbf{P b}$ & $\mathbf{V}$ & $\mathrm{Zn}$ & $\mathrm{H}_{2} \mathrm{~S}$ \\
\hline $\begin{array}{l}\text { VN1 } \\
\text { (this } \\
\text { study) }\end{array}$ & 784 & 101 & 3.15 & -44 & -60 & 1638 & -1.00 & -1.033 & 139 & 22 & 161 & 954 & 0.00 \\
\hline $\begin{array}{l}\text { VN3 } \\
\text { (this } \\
\text { study) }\end{array}$ & n.d. & 602 & 0.00 & -6.30 & 126 & 63 & 0.60 & 9009 & 50 & 60 & 50 & 154 & 11,987 \\
\hline $\begin{array}{c}\text { SL } \\
{[24]}\end{array}$ & n.d. & 5040 & -9.45 & -1654 & 340,200 & -882 & -0.07 & 658 & 1260 & 95 & 315 & 1134 & -135 \\
\hline $\begin{array}{l}\text { SR1 } \\
{[24]}\end{array}$ & n.d. & 5355 & 9.45 & 630 & -4095 & -1166 & -3.92 & 1093 & 504 & 4199 & 5670 & 3339 & -132 \\
\hline
\end{tabular}

In order to compare our results with those reported for two tourist port areas of the Gulf of Trieste (Northern Adriatic Sea) [24], the benthic fluxes estimated at the two marinas were re-calculated, using another method of calculation [28]. Our fluxes are generally one or two orders of magnitude lower than those estimated at these two marinas (Table 4), where the highest influxes are also estimated and attributed to the precipitation of these metal(loid)s both with Fe and Mn oxy-hydroxides (and/or sulphides) or as sulphates, and complexation with the organic matter at the SWI [55], due to the oxic condition found in both benthic chambers during the experiments [24].

The benthic fluxes measured with the benthic chamber (Table 4), which represent the total fluxes, differed substantially from the diffusive fluxes (Table 3). This observation has 
already been reported in previous studies $[12,23,24]$ and attributed to intense sediment bioturbation/bio-irrigation and/or insufficient resolution in the characterisation of the concentration gradient close to the SWI in calculating the diffusive fluxes $[51,54]$. Indeed, the diffusive flux is an instantaneous measure, while the benthic flux is a measure over time, and it integrates the processes in the entire studied sedimentary column.

\section{Conclusions}

In this anthropogenically modified lagoon environment, notable differences in terms of concentration and trends in sediment profiles were not observed between the two sites. Cadmium and $\mathrm{Hg}$ showed high EF values at both sites (5-20), thus indicating a "significant enrichment", as compared to the local background. Mercury contamination is mainly due to the legacy of the past extraction activity at the Idrija mining district (NW Slovenia), whereas $\mathrm{Cd}$ enrichments are attributed to more recent undefined anthropogenic sources. Excluding $\mathrm{Cd}$ and $\mathrm{Hg}$, low enrichment factors $(\mathrm{EF})$ were found at both sites; however, slightly higher EF values were observed at VN3 (EF up to 2.27), with respect to VN1 (EF up to 1.44 ).

Except for Mn, the labile percentage of metal(loid)s was low or absent, thus suggesting that the amount of elements in association with $\mathrm{Fe}$ and $\mathrm{Mn}$ oxides and hydroxides was scarce. The results from porewaters showed the highest concentration of $\mathrm{Al}, \mathrm{Cd}, \mathrm{Cu}, \mathrm{Fe}$, $\mathrm{Pb}$ and $\mathrm{Zn}$ at VN3 and, in general, the metal(loid)s roughly followed the $\mathrm{H}_{2} \mathrm{~S}$ trend. The adsorption/release of some metal(loid)s associated with Fe and Mn oxy-hydroxides and $\mathrm{FeS} / \mathrm{FeS}_{2}$ or precipitation as sulphides govern their mobility. The $\log \mathrm{K}_{\mathrm{D}}$ values at the two sites did not differ significantly and were found to be comparable with values reported in the literature. A positive diffusive flux was found for almost all metal(loid)s, thus indicating a tendency to migrate from porewaters to the overlying water, especially with regard to Fe and Mn. However, during the benthic chamber experiment, high metal(loid) concentrations and great variability over time were observed at the more oxic site, VN1, compared to the anoxic site, VN3. The benthic fluxes, mostly effluxes, showed significant differences between the two sites, with the highest values estimated for Fe at VN1 and $\mathrm{Mn}$ at VN3, indicating of a release from the sediment to the overlying water column. Effluxes for all metal(loid)s, excluding $\mathrm{Cr}$, and $\mathrm{H}_{2} \mathrm{~S}$ were estimated at $\mathrm{VN} 3$ and associated with the anoxic conditions that characterised this site. Conversely, the influxes of $\mathrm{Cr}$, $\mathrm{Cu}, \mathrm{Hg}$ and $\mathrm{Mn}$ estimated at VN1 could be the consequence of the immobilisation of $\mathrm{Mn}$ and concomitantly other involved metals. However, the highest benthic effluxes, except for $\mathrm{As}$ and $\mathrm{Pb}$, were observed at this oxic site (VN1), thus indicating a major release from the sediment to the water column of $\mathrm{Al}, \mathrm{Fe}, \mathrm{Ni}, \mathrm{V}, \mathrm{Cd}$ and $\mathrm{Zn}$. A possible explanation could be the intense bioturbation produced by benthic organisms that plays a major role in the significant variability of the metal benthic fluxes in the lagoon. Overall, the mobility of metal(loid)s from the sediment to the porewaters and to the overlying water column, although driven by an intense remineralisation of the organic matter and bioturbation, appears to be limited and related to the specific environmental conditions of the experimental site. Therefore, it seems that the presence of metal(loid)s in fish farm sediments, excluding $\mathrm{Hg}$, for which this semi-confined environment was found to be a potential bioreactor for $\mathrm{MeHg}$ production, [12] do not represent a severe risk for the aquaculture activity.

Supplementary Materials: The following are available online, at https://www.mdpi.com/2076 $-3417 / 11 / 5 / 2350 /$ s1. Figure S1: Metal(loid) profiles in VN1 and VN3 sediment cores. Table S1: Enrichment factors (EFs) calculated for all metal(loid)s for each level of the sediment cores (VN1 and VN3). Table S2: Log $K_{D}$ values for all metal(loid)s in each level of cores VN1 and VN3. 
Author Contributions: Data curation, conceptualisation, methodology, writing-original draft and writing-review, E.P. (Elisa Petranich), E.P. (Elena Pavoni), J.F. and S.C.; analyses, E.P. (Elisa Petranich), E.P. (Elena Pavoni) and M.C.; processing of data, E.P. (Elisa Petranich); data survey, E.P. (Elisa Petranich) and S.C.; final editing, E.P. (Elisa Petranich) All authors have read and agreed to the published version of the manuscript.

Funding: This research received no external funding.

Institutional Review Board Statement: Not applicable.

Informed Consent Statement: Not applicable.

Data Availability Statement: The data presented in this study are available on request from the corresponding author.

Acknowledgments: The research activity was partially supported by the University of Trieste (Finanziamento di Ateneo per progetti di ricerca scientifica-FRA 2014, reference Stefano Covelli). Stefano Cirilli and Stefano Sponza, from the University of Trieste, are warmly acknowledged fort their technical assistance during sampling operations. A special thanks to the manager of the investigated fish farm, Claudio Furlanut, for his valuable support and kind hospitality at the fish farm, during field work. Karry Close is warmly acknowledged for proofreading the manuscript. The anonymous reviewers are greatly acknowledged for their critical reviews and useful suggestions, which improved the quality of the manuscript.

Conflicts of Interest: The authors declare no conflict of interest.

\section{References}

1. Mason, R.P. Trace Metals in Aquatic Systems; Wiley-Blackwell: Oxford, UK, 2013; ISBN 978-1-4051-6048-3.

2. Bastami, K.D.; Neyestani, M.R.; Molamohyedin, N.; Shafeian, E.; Haghparast, S.; Shirzadi, I.A.; Baniamam, M. Bioavailability, Mobility, and Origination of Metals in Sediments from Anzali Wetland, Caspian Sea. Mar. Pollut. Bull. 2018, 136, 22-32. [CrossRef]

3. Roberts, D.A. Causes and Ecological Effects of Resuspended Contaminated Sediments (RCS) in Marine Environments. Environ. Int. 2012, 40, 230-243. [CrossRef]

4. Kouassi, N.L.B.; Yao, K.M.; Sangare, N.; Trokourey, A.; Metongo, B.S. The Mobility of the Trace Metals Copper, Zinc, Lead, Cobalt, and Nickel in Tropical Estuarine Sediments, Ebrie Lagoon, Côte d'Ivoire. J. Soils Sediments 2019, 19, 929-944. [CrossRef]

5. Schroeder, H.; Fabricius, A.-L.; Ecker, D.; Ternes, T.A.; Duester, L. Impact of Mechanical Disturbance and Acidification on the Metal(Loid) and C, P, S Mobility at the Sediment Water Interface Examined Using a Fractionation Meso Profiling ICP-QQQ-MS Approach. Sci. Total Environ. 2019, 651, 2130-2138. [CrossRef] [PubMed]

6. Canuto, F.A.B.; Garcia, C.A.B.; Alves, J.P.H.; Passos, E.A. Mobility and Ecological Risk Assessment of Trace Metals in Polluted Estuarine Sediments Using a Sequential Extraction Scheme. Environ. Monit. Assess. 2013, 185, 6173-6185. [CrossRef] [PubMed]

7. Qiu, Y.-W. Bioaccumulation of Heavy Metals Both in Wild and Mariculture Food Chains in Daya Bay, South China. Estuar. Coast. Shelf Sci. 2015, 163, 7-14. [CrossRef]

8. Acquavita, A.; Covelli, S.; Emili, A.; Berto, D.; Faganeli, J.; Giani, M.; Horvat, M.; Koron, N.; Rampazzo, F. Mercury in the sediments of the Marano and Grado lagoon (northern Adriatic Sea): Sources, distribution and speciation. Estuar. Coast. Shelf Sci. 2012, 13, 20-31. [CrossRef]

9. Brambati, A. Metalli Pesanti Nelle Lagune di Marano e Grado. Piano di Studi Finalizzato All'accertamento Della Presenza di Eventuali Sostanze Persistenti Nelle Lagune di Grado e Marano e al Loro Risanamento; Regione Autonoma Friuli-Venezia Giulia: Trieste, Italy, 1997.

10. Piani, R.; Covelli, S. Contributo antropico di metalli pesanti e 137Cs nei sedimenti del bacino di Buso (Laguna di Marano e Grado, Italia settentrionale). Studi Trentini Sci. Nat. Acta Geol. 2001, 77, 169-177.

11. Ramieri, E.; Barbanti, A.; Picone, M.; Menchini, G.; Bressan, E.; Forno, E.D. Integrated Plan for the Sustainable Management of the Lagoon of Marano and Grado. Littoral 2011, 11. [CrossRef]

12. Petranich, E.; Covelli, S.; Acquavita, A.; Faganeli, J.; Horvat, M.; Contin, M. Evaluation of Mercury Biogeochemical Cycling at the Sediment-Water Interface in Anthropogenically Modified Lagoon Environments. J. Environ. Sci. 2018, 68, 5-23. [CrossRef]

13. Petranich, E.; Covelli, S.; Acquavita, A.; De Vittor, C.; Faganeli, J.; Contin, M. Benthic Nutrient Cycling at the Sediment-Water Interface in a Lagoon Fish Farming System (Northern Adriatic Sea, Italy). Sci. Total Environ. 2018, 644, 137-149. [CrossRef] [PubMed]

14. Covelli, S.; Faganeli, J.; De Vittor, C.; Predonzani, S.; Acquavita, A.; Horvat, M. Benthic Fluxes of Mercury Species in a Lagoon Environment (Grado Lagoon, Northern Adriatic Sea, Italy). Appl. Geochem. 2008, 23, 529-546. [CrossRef]

15. Acquavita, A.; Aleffi, I.F.; Benci, C.; Bettoso, N.; Crevatin, E.; Milani, L.; Tamberlich, F.; Toniatti, L.; Barbieri, P.; Licen, S.; et al. Annual Characterization of the Nutrients and Trophic State in a Mediterranean Coastal Lagoon: The Marano and Grado Lagoon (Northern Adriatic Sea). Reg. Stud. Mar. Sci. 2015, 2, 132-144. [CrossRef] 
16. Emili, A.; Acquavita, A.; Koron, N.; Covelli, S.; Faganeli, J.; Horvat, M.; Žižek, S.; Fajon, V. Benthic Flux Measurements of Hg Species in a Northern Adriatic Lagoon Environment (Marano and Grado Lagoon, Italy). Estuar. Coast. Shelf Sci. 2012, 113, 71-84. [CrossRef]

17. De Vittor, C.; Faganeli, J.; Emili, A.; Covelli, S.; Predonzani, S.; Acquavita, A. Benthic Fluxes of Oxygen, Carbon and Nutrients in the Marano and Grado Lagoon (Northern Adriatic Sea, Italy). Estuar. Coast. Shelf Sci. 2012, 113, 57-70. [CrossRef]

18. Hedges, J.L.; Stern, J.H. Carbon and Nitrogen Determinations of Carbonate Containing Solids. Limnol. Oceanogr. 1984, $29,657-663$. [CrossRef]

19. EPA. Method 3052 Microwave Assisted Acid Digestion of Siliceous and Organically Based Matrices; EPA: Washington, DC, USA, 1996.

20. EPA. Method 7473 (SW-846) Mercury in Solids and Solutions by Thermal Decomposition, Amalgamation, and Atomic Absorption Spectrophotometry; EPA: Washington, DC, USA, 1998.

21. Adami, G.; Barbieri, P.; Reisenhofer, E. A comparison on five sediment decomposition procedures for determining anthropogenic trace metal pollution. Int. J. Environ. Anal. Chem. 1999, 75, 251-260. [CrossRef]

22. EPA. Method 1631, Revison e. Mercury in Water by Oxidation, Purge and Trap, and Cold Vapor Atomic Fluorescence Spectrometry; EPA: Washington, DC, USA, 2002.

23. Emili, A.; Acquavita, A.; Covelli, S.; Spada, L.; Di Leo, A.; Giandomenico, S.; Cardellicchio, N. Mobility of Heavy Metals from Polluted Sediments of a Semi-Enclosed Basin: In Situ Benthic Chamber Experiments in Taranto's Mar Piccolo (Ionian Sea, Southern Italy). Environ. Sci. Pollut. Res. 2016, 23, 12582-12595. [CrossRef] [PubMed]

24. Petranich, E.; Croce, S.; Crosera, M.; Pavoni, E.; Faganeli, J.; Adami, G.; Covelli, S. Mobility of Metal(loid)s at the Sediment-Water Interface in Two Tourist Port Areas of the Gulf of Trieste (Northern Adriatic Sea). Environ. Sci. Pollut. Res. 2018, 25, 26887-26902. [CrossRef]

25. Boudreau, B.P. Metals and Models: Diagenetic Modelling in Freshwater Lacustrine Sediments. Met. Models Diagenetic Model. Freshw. Lacustrine Sediments 1999, 22, 227-251.

26. Li, Y.H.; Gregory, S. Diffusion of Ions in Sea Water and in Deep-Sea Sediments. Geochim. Cosmochima Acta 1974, 38, 703-714.

27. Gobeil, C.; Cossa, D. Mercury in Sediments and Sediment Pore Water in the Laurentian Trough. Can. J. Fish. Aquat. 1993, 50, 1794-1800. [CrossRef]

28. Zago, C.; Capodaglio, G.; Ceradini, S.; Ciceri, G.; Abelmoschi, L.; Soggia, F.; Cescon, P.; Scarponi, G. Benthic Fluxes of Cadmium, Lead, Copper and Nitrogen Species in the Northern Adriatic Sea in Front of the River Po Outflow, Italy. Sci. Total Environ. 2000, 246, 121-137. [CrossRef]

29. Oliveri, P.; Malegori, C.; Casale, M. Chemometrics: Multivariate Analysis of Chemical Data. In Chemical Analysis of Food, 2nd ed.; Pico, Y., Ed.; Elsevier: Amsterdam, The Netherlands, 2020; ISBN 9780128132661.

30. Oliveri, P.; Malegori, C.; Simonetti, R.; Casale, M. The impact of signal pre-processing on the final interpretation of analytical outcomes-A tutorial. Anal. Chim. Acta 2019, 1058, 9-17. [CrossRef] [PubMed]

31. Leardi, R.; Melzi, C.; Polotti, G. CAT (Chemometric Agile Tool). Available online: http://gruppochemiometria.it/index.php/ software (accessed on 3 September 2019).

32. Shepard, F.P. Nomenclature Based on Sand-Silt-Clay Ratios. J. Sediment. Petrol. 1954, 24, 151-158.

33. Goñi, M.A.; Teixeira, M.J.; Perkey, D.W. Sources and Distribution of Organic Matter in a River-Dominated Estuary (Winyah Bay, SC, USA). Estuar. Coast. Shelf Sci. 2003, 57, 1023-1048. [CrossRef]

34. Ogrinc, N.; Fontolan, G.; Faganeli, J.; Covelli, S. Carbon and Nitrogen Isotope Compositions of Organic Matter in Coastal Marine Sediments (the Gulf of Trieste, N Adriatic Sea): Indicators of Sources and Preservation. Mar. Chem. 2005, 95, 163-181. [CrossRef]

35. Covelli, S.; Fontolan, G.; Faganeli, J.; Ogrinc, N. Anthropogenic Markers in the Holocene Stratigraphic Sequence of the Gulf of Trieste (Northern Adriatic Sea). Mar. Geol. 2006, 230, 29-51. [CrossRef]

36. Covelli, S.; Langone, L.; Acquavita, A.; Piani, R.; Emili, A. Historical Flux of Mercury Associated with Mining and Industrial Sources in the Marano and Grado Lagoon (Northern Adriatic Sea). Estuar. Coast. Shelf Sci. 2012, 113, 7-19. [CrossRef]

37. Sutherland, R.A. Bed Sediment-Associated Trace Metals in an Urban Stream, Oahu, Hawaii. Environ. Geol. 2000, 39, 611-627. [CrossRef]

38. Covelli, S.; Faganeli, J.; Horvat, M.; Brambati, A. Mercury Contamination of Coastal Sediments as the Result of Long-Term Cinnabar Mining Activity (Gulf of Trieste, Northern Adriatic Sea). Appl. Geochem. 2001, 16, 541-558. [CrossRef]

39. Covelli, S.; Piani, R.; Acquavita, A.; Predonzani, S.; Faganeli, J. Transport and Dispersion of Particulate Hg Associated with a River Plume in Coastal Northern Adriatic Environments. Mar. Pollut. Bull. 2007, 55, 436-450. [CrossRef]

40. Bastami, K.D.; Neyestani, M.R.; Esmaeilzadeh, M.; Haghparast, S.; Alavi, C.; Fathi, S.; Nourbakhsh, S.; Shirzadi, E.A.; Parhizgar, R. Geochemical Speciation, Bioavailability and Source Identification of Selected Metals in Surface Sediments of the Southern Caspian Sea. Mar. Pollut. Bull. 2017, 114, 1014-1023. [CrossRef]

41. Warnken, K.W.; Gill, G.A.; Griffin, L.L.; Santschi, P.H. Sediment-Water Exchange of Mn, Fe, Ni and Zn in Galveston Bay, Texas. Mar. Chem. 2001, 73, 215-231. [CrossRef]

42. Huerta-Diaz, M.A.; Morse, J.W. Pyritization of Trace Metals in Anoxic Marine Sediments. Geochim. Cosmochim. Acta 1992, 56, 2681-2702. [CrossRef]

43. Rigaud, S.; Radakovitch, O.; Couture, R.-M.; Deflandre, B.; Cossa, D.; Garnier, C.; Garnier, J.-M. Mobility and Fluxes of Trace Elements and Nutrients at the Sediment-Water Interface of a Lagoon under Contrasting Water Column Oxygenation Conditions. Appl. Geochem. 2013, 31, 35-51. [CrossRef] 
44. Mehta, N.; Kocar, B.D. Geochemical conditions conductive for retention of trace elements and radionuclides during shale-fluid interactions. Environ. Sci. Proc. Imp. 2019, 21, 1764-1776.

45. Froelich, P.N.; Klinkhammer, G.P.; Bender, M.L.; Luedtke, N.A.; Heath, G.R.; Cullen, D.; Dauphin, P.; Hammond, D.; Hartman, B.; Maynard, V. Early Oxidation of Organic Matter in Pelagic Sediments of the Eastern Equatorial Atlantic: Suboxic Diagenesis. Geochim. Cosmochim. Acta 1979, 43, 1075-1090. [CrossRef]

46. Lee, P.-K.; Baillif, P.; Touray, J.-C. Geochemical Behaviour and Relative Mobility of Metals (Mn, Cd, Zn and Pb) in Recent Sediments of a Retention Pond along the A-71 Motorway in Sologne, France. Environ. Geol. 1997, 32, 142-152. [CrossRef]

47. Hammerschmidt, C.R.; Fitzgerald, W.F. Geochemical Controls on the Production and Distribution of Methylmercury in Near-Shore Marine Sediments. Environ. Sci. Technol. 2004, 38, 1487-1495. [CrossRef] [PubMed]

48. Gavriil, A.M.; Angelidis, M.O. Metal Diagenesis in a Shallow Semi-Enclosed Marine System in the Aegean Sea, Greece. Estuar. Coast. Shelf Sci. 2006, 70, 487-498. [CrossRef]

49. De Vittor, C.; Relitti, F.; Kralj, M.; Covelli, S.; Emili, A. Oxygen, Carbon, and Nutrient Exchanges at the Sediment-Water Interface in the Mar Piccolo of Taranto (Ionian Sea, Southern Italy). Environ. Sci. Pollut. Res. 2016, 23, 12566-12581. [CrossRef] [PubMed]

50. Bettoso, N. Macrozoobenthos Monitoring in Relation to Dredged Sediment Disposal: The Case of the Marano and Grado Lagoon (Northern Adriatic Sea, Italy). Reg. Stud. Mar. Sci. 2020, 33, 100916. [CrossRef]

51. Point, D.; Monperrus, M.; Tessier, E.; Amouroux, D.; Chauvaud, L.; Thouzeau, G.; Jean, F.; Amice, E.; Grall, J.; Leynaert, A.; et al. Biological Control of Trace Metal and Organometal Benthic Fluxes in a Eutrophic Lagoon (Thau Lagoon, Mediterranean Sea, France). Estuar. Coast. Shelf Sci. 2007, 72, 457-471. [CrossRef]

52. Ehrlich, H.L.; Newman, D.K.; Kappler, A. Ehrlich's Geomicrobiology; CRC Press: Boca Raton, FL, USA, 2015; ISBN 978-0-367-65872-4.

53. Westerlund, S.F.G.; Anderson, L.G.; Hall, P.O.J.; Iverfeldt, Å.; Van Der Loeff, M.M.R.; Sundby, B. Benthic Fluxes of Cadmium, Copper, Nickel, Zinc and Lead in the Coastal Environment. Geochim. Cosmochim. Acta 1986, 50, 1289-1296. [CrossRef]

54. Covelli, S.; Faganeli, J.; Horvat, M.; Brambati, A. Porewater Distribution and Benthic Flux Measurements of Mercury and Methylmercury in the Gulf of Trieste (Northern Adriatic Sea). Estuar. Coast. Shelf Sci. 1999, 48, 415-428. [CrossRef]

55. Muresan, B.; Cossa, D.; Jézéquel, D.; Prévot, F.; Kerbellec, S. The Biogeochemistry of Mercury at the Sediment-Water Interface in the Thau Lagoon. 1. Partition and Speciation. Estuar. Coast. Shelf Sci. 2007, 72, 472-484. [CrossRef] 